\title{
The Effect of Logistical-Crossfunctional Drivers on the Competitive Strategy of the Supply Chain of SMEs: A Case Study
}

\author{
Sumarsono Sumarsono *, Nur Muflihah \\ Department of Industrial Engineering, University of Hasyim Asy'ari Jombang, Indonesia \\ Jl. Irian Jaya no.55 Tebuireng, Jombang, East Java, Indonesia \\ *Corresponding author: sonsumarsono13@gmail.com
}

\section{ARTICLE INFO}

Article history

Received September 29, 2020

Revised February 25, 2021

Accepted February 26, 2021

Available Online February 28, 2021

Keywords

Competitive Strategy

Logistical-Crossfunctional

Supply-chain

PLS-SEM

SMEs

\begin{abstract}
Small and Medium Enterprises (SMEs) dominate the business world in Indonesia with a high Gross Domestic Product contribution. However, SMEs are unable to compete with large industries due to uncompetitive supply chains. The logisticalcrossfunctional aspect of drivers is an aspect driving a competitive supply chain. This study aims to examine the effect of logisticalcrossfunctional drivers on the competitive strategy of the supply chain for SMEs in Indonesia. The case study was conducted in SMEs scattered in East Java, Indonesia. The data analysis method used PLS-SEM. The results showed that the logisticalcrossfunctional aspects of SME drivers have a significant effect on the supply chain competitive strategy. The implications of the research results are used to develop supply chain strategies for SMEs with a priority scale of logistical-crossfunctional drivers such as 1) facilities; 2) sourcing; 3) information; 4) transportation; 5) inventory; and 6) pricing.
\end{abstract}

This is an open-access article under the CC-BY-SA license.

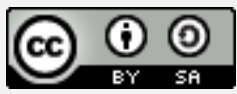

\section{Introduction}

Small and Medium Enterprises (SMEs) still dominate business lines in Indonesia with a contribution of Gross Domestic Gross (GDP) around 58\%-61\% [1]. According to Tambunan [1], SMEs in Indonesia have several characteristics, namely: 1) they are large in number and absorb much labor; 2) uses simple equipment and sourcing local raw materials; 3) the majority are located in rural areas by local transportation; 4) operates with their capital, to limit the amount of inventory; 5) human resource skills are still lacking in exploring the cheapest supplier market which has an impact on pricing policies; and 6) relatively low application of information technology. According to Chopra and Meindl [2]; Pujawan and Mahendrawathi [3]; Helmi, et al. [4]; Eicker and Cilliers [5]; Rana [6], aspects of facilities, inventory, and transportation are logistical drivers that have an efficient and competitive effect on supply chains. Meanwhile, the information, sourcing, and pricing factors are crossfunctional drivers with an efficient and responsive (competitive) effect on the supply chain. 
The logistical-cross-functional drivers' aspect in SMEs' supply chain is vital to be studied as an SME development strategy. Several researchers have found the limitations of the logistical-cross-functional drivers' aspect that hinder SMEs. Research conducted by Madyaratry, et al. [7], and Rita [8] found that SME production facilities are SMEs' limitations in their competitive strategy. It is due to a large number of SMEs using only conventional equipment. In the inventory aspect, limited capital affects inventory capacity [9]. In addition, research on transportation aspects is generally to minimize transportation costs. It can be an obstacle to customer satisfaction. According to Ong, et al. [10], on-time delivery service is very influential on consumer attitudes and loyalty. In Sari's research [11], the information aspect significantly impacts the industrial era 4.0. However, the analysis results show that SMEs are not yet ready to face the industrial era 4.0. In addition, Sasongko [9] stated that the sourcing of raw material suppliers for SMEs is limited. It was triggered by the insufficient human resource skills of SMEs in managing the cheapest suppliers. Furthermore, [12] also explained that the limitations of supplier sourcing are caused by a lack of network relationships and not participating in government assistance programs. Other obstacles are the lack of partnerships with suppliers [13], the absence of a supplier contract [14], and a mismatch in the amount of supply [15]. Human resource skills lack digging up information on the cheapest supplier options [1] [9]. It has an impact on the selling price of the product, which is not competitive. Referring to these limitations, it is necessary to study logistical-crossfunctional SME drivers' effect on supply chain competitive strategies.

Many studies have examined the development of SMEs through the logisticalcrossfunctional drivers' aspects of the supply chain. Panjaitan, et al. [16] explained that SMEs' strengthening is carried out through an integrative supply chain relationship. Inefficient supply chains lead to less competitiveness [2], [4]. An efficient supply chain is influenced by logistical drivers, which include facilities, inventory, and transportation. Responsive supply chains are influenced by crossfunctional drivers, which include information, sourcing, and pricing. According to Ganguly and Kumar [17], sourcing, finance, information, and manufacturing are sources of supply chain risks that need to be anticipated. Wulandari, et al. [18] stated that good SME supply chain management has a significant effect on performance. More specifically, on the aspect of facilities, the research by [7] found that facilities have to be converted to modern equipment to be more competitive. Facilities related to location-allocation capacity are drivers of competitive supply chains [19]. In the research on developing the sourcing aspect, supplier partnerships can maintain SMEs' supply performance [13]. SMEs need to choose suppliers who can maintain the amount of supply promised [15]. Furthermore, SMEs need a supply chain contract to maintain supply and price [14]. In research on developing the information aspect, information technology to develop a competitive level is also very much needed [20]. Furthermore, Electronic Data Interchange has been shown to improve customer service and loyalty [21]. Research conducted by Kantari, et al. [22] indicated that meeting demand with appropriate transportation impacts service supply performance. Similarly, in the development research on pricing aspects, Yu and Zhang [23] proposed a pricing model between parties to coordinate the supply chain. On the other hand, Gan, et al. [24] explained that appropriate prices on the distribution channel affect the supply chain's profit performance.

No one has jointly examined the effect of SME drivers' logistical-cross-functional aspects on supply chain competitive strategies in previous studies. In this article, the study proposes a predictive model that can examine the aspects of the relationship between multi-variables thoroughly simultaneously. This study aims to examine the effect of logistical-crossfunctional SME drivers on supply chain competitive strategies. This 
study took a case study of SMEs in East Java Province, Indonesia. In East Java, Indonesia, 9,782,262 business units are consisting of $93.37 \%$ micro-enterprises, $5.92 \%$ small businesses, and $0.7 \%$ medium enterprises [25]. This amount makes a significant contribution to the economy and can absorb labor.

This study's paper structure is presented as follows: conceptual framework, research hypothesis, data collection, and data analysis are presented in section 2 (method). The outer model testing results, inner model testing, analysis model, and discussion are presented in section 3 . The final section presents conclusions and suggestions for further research.

\section{Methods}

The research method used a quantitative analytic design. Methods of data analysis implemented a Partial Least Square Structural Equation Modeling (PLS-SEM). PLS-SEM is a multivariate analysis method to predict the causal relationship between exogenous and endogenous variables simultaneously. The advantage of this method is that it is possible to use a mediator and moderator variables [26] [27] [28] [29] [30].

\subsection{Conceptual Framework \& Research Hypotheses}

\subsubsection{Conceptual Framework}

The complete conceptual framework model for the SME supply chain competitive strategy's influence is shown in Fig. 1. This conceptual framework contains two kinds of variables, namely the indicator variable and the factor variable. Factor variables are variables measured based on indicator variables (26 indicators). The research framework's six-factor variables are facilities, inventory, transportation, information, sourcing, and pricing. The conceptual framework is adapted from the research of Chopra and Meindl [2]; Pujawan and Mahendrawathi [3]; Galankashi and Helmi [14]; Eicker and Cilliers [5]; Rana [6]. The conceptual framework contains the relationship between SME drivers' exogenous logistical-cross-functional variables and the endogenous variables of supply chain competitive strategy. Logistical drivers include facilities, inventory and transportation factors that have an impact on efficient and responsive strategies. Crossfunctional drivers include information, sourcing and pricing factors that have an impact on efficient and responsive strategies. The descriptions of factors and indicators in this study are presented in Table 1.

\subsubsection{Research Hypotheses}

This study constructed two hypotheses (major and minor) that needed to be proven. In the major hypothesis, the model of the influence of logistical-crossfunctional drivers on the competitive strategy of SMEs' supply chain in East Java is good and relevant. The criteria for a good prediction model use the coefficient of determination $\left(\mathrm{R}^{2}\right)$, and the criteria for the relevant prediction model use the $\mathrm{Q}^{2}$ value [29] [30] [31].

In the minor hypothesis, this study makes several hypotheses such as:

H1: There is an effect of SME facilities on the supply chain competitive strategy.

H2: There is an effect of SME's inventory on the supply chain competitive strategy.

H3: There is an effect of SME transportation on the supply chain competitive strategy.

H4: There is an effect of SME information on supply chain competitive strategies.

H5: There is an effect of SME sourcing on the supply chain competitive strategy.

H6: There is an effect of SME pricing on supply chain competitive strategies. 
Table 1. Descriptions of factors and indicators in the study

Endogenous

Factors:

Competitive

Indicators

Description Indicators

Strategy

Competitive

Efficiency

strategy

$[5] ;[6]$

Responsive

Efficiency indicators are measured from logistical drivers, which include facilities, inventory, transportation.

\section{Exogenous}

Factors:

Logistical-

Responsive indicators are measured by crossfunctional drivers, which include information, sourcing, pricing.

Crossfunctional

Facilities

[5]; [19];

\begin{tabular}{ll} 
& Flow Time \\
\cline { 2 - 2 } & Location \\
\cline { 2 - 2 } Inventory [5] & Utility \\
\cline { 2 - 2 } & Fverage \\
& FillRate \\
\cline { 2 - 2 } & Safety \\
\cline { 2 - 2 } Transportation & Variation \\
[5]; [10]; [22] & Incoming Size \\
\cline { 2 - 2 } & Model \\
\cline { 2 - 2 } & Outbound Size \\
\cline { 2 - 2 } & Route \\
\hline Information & EDI (Electronic \\
[19]; [20] & Data Interchange) \\
& Media
\end{tabular}

Sourcing [15] Lead Time Supply

Price Purchase The average price of goods/materials from suppliers (Average purchase price).

Quality Supply Quality of goods/materials from suppliers (Supply quality).

Quantity Purchase The number of orders for goods/materials that can be fulfilled by the supplier (Average purchase quantity).

Selection Supplier Choice of primary suppliers for materials/goods (Supplier selection).

Pricing: $\quad$ Day Outstanding Payment methods from consumers and suppliers.

[24]
Profit Margin

SalePrice

Supplier Price
The amount of profit per product (Profit margin). Average selling price to consumers (Average sale price). Average purchasing price from suppliers (Average order price) 


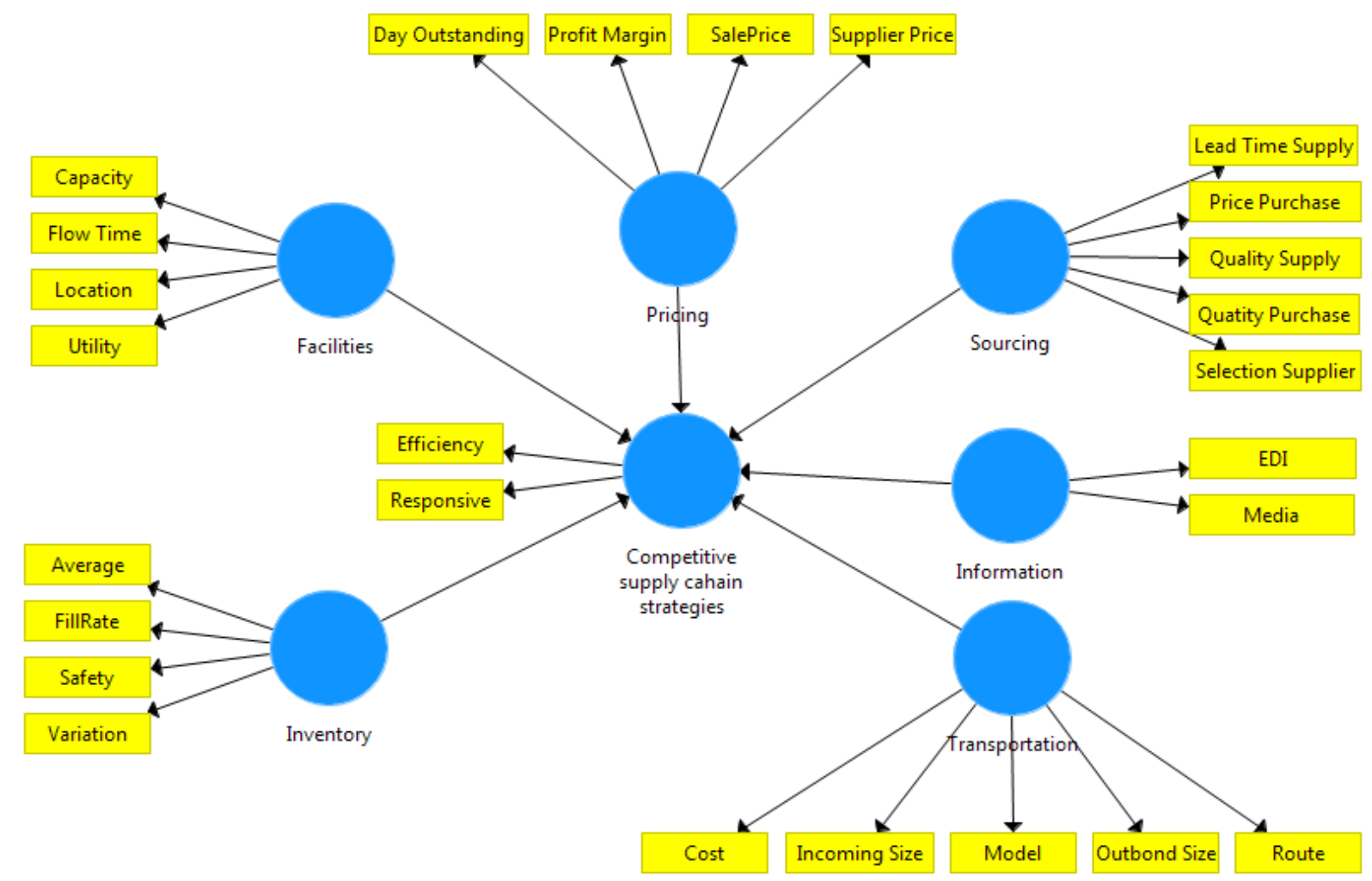

Fig. 1.The influence of logistical-crossfunctional drivers on the competitive strategy of the supply chain of SMEs

\subsection{Data Collection}

This research was conducted in SMEs located in East Java Province, Indonesia. Respondents were SME owners or executors. Data collection was carried out using surveys and non-probability sampling techniques using purposive sampling. The survey was conducted by combining direct observation and a questionnaire presented on the google form. Surveyors came to prospective respondents. If the respondent was willing, then the respondent answered the questions provided. The questionnaire was designed into six (6) main sections concerning the concept proposed by Chopra and Meindl [2] and Pujawan and Mahendrawathi [3]. A summary of the contents of the questionnaire is presented Table 1.

The questionnaire used a Likert scale with answer choices ranging from 1 "strongly disagree" to 5 "strongly agree". The research sample was taken from 100 SMEs in East Java province, Indonesia. According to Hair, et al. [26] and Sarstedt, et al. [30], PLS-SEM can be used as a causality prediction data analysis when the sample size is small (minimum 30).

\subsection{Data Analysis}

The PLS-SEM method was used to predict structural relationships between variables. In PLS-SEM, there were two groups of testing, namely 1) Testing the outer model, testing the validity-reliability of the indicators measuring the factor variables; 2) Testing the inner model, testing the relationship between the influence of exogenous factors on endogenous and evaluating the goodness of the prediction of the model [32] [30]. 


\subsubsection{Outer Model Testing}

The purpose of testing the outer model was to test the validities of the indicators. Validity testing includes convergent validity with the criteria for the loading factor value and Average Variance Extracted (AVE). Hair Jr, et al. [33], Malik [34], Giyanti and Indriastiningsih [35], and Ortt, et al. [13] have stated that the indicator is valid if the factor loading value is greater than 0.7. The value AVE is greater than 0.5. There is an additional opinion from Hair, et al. [32] and Tentama and Subardjo [36], which states that the weakest factor loading can be accepted is 0.40 or close to 0.40 . It can be used when the indicator is small in a factor variable. Furthermore, observing the Composite Reliability (CR) value can test the factor variables' reliability. Malik [34], Giyanti and Indriastiningsih [35], and [13] stated that a CR value greater than 0.7 means that the factor variable is fairly reliable.

\subsubsection{Inner Model Testing}

The purpose of testing the inner model is to examine the relationship between the influence of exogenous and endogenous factors. In addition, this test aims to evaluate the predictability of endogenous variables. Hair Jr, et al. [33] confirmed that testing the influence relationship can be done by evaluating the t-test criteria. If the t-statistic is greater than the t-table, it is concluded that the effect of exogenous factors on endogenous factors is significant. The t-table value using error tolerance (a) $=5 \%$ and the number of bootstrapping data is 500 , then the t-table value $=\mathrm{t}(\mathrm{df}=\mathrm{n}-1 ; \mathrm{\alpha} / 2)=\mathrm{t}(499 ; 0.025)=1.96$.

The evaluation of the prediction model's suitability utilized the criteria for the coefficient of determination $\left(\mathrm{R}^{2}\right)$ and predicted relevance $\left(\mathrm{Q}^{2}\right)$. The value of the coefficient of determination $\left(\mathrm{R}^{2}\right)$ was used to evaluate how much variation of the endogenous factors exogenous factors can explain. The criteria for $\mathrm{R}^{2}$, according to Hair Jr, et al. [33], is that if $\mathrm{R}^{2}$ is $<0.25$, then it is called weak. However, if it is 0.25 to 0.5 , it is sufficient, and if it is 0.5 to 0.75 , it is considered good. Furthermore, the model is very good when the value of $\mathrm{R}^{2}$ is $>0.75$. The $\mathrm{Q}^{2}$ value aims to determine the predictive relevance of endogenous factors. If the value of $\mathrm{Q}^{2}$ is greater than zero, then the endogenous factor has the relevant ability to predict.

\section{Results and Discussion}

\subsection{Outer Model Testing Results}

The validity and reliability test results on the outer model can be seen in Table 2 . The initial outer model validity test results showed that of the 26 indicators, there was one invalid indicator because these indicators had a loading factor value of less than 0.5. This indicator was supplier price. However, from the significant test of the indicator weight, the supplier price is significant because the $\mathrm{P}$-value is $0.019<\mathrm{P}$-value 0.05 . Therefore, the supplier price is maintained within the pricing factor. Furthermore, from the reliability test results, it was known that all factors had a CR ranging from 0.69 to 0.88. In conclusion, from the validity-reliability test, the second outer model contained valid and reliable variable

\subsection{Inner Model Test Results}

The value of statistics on the inner model is in the influence coefficient, t-statistics, the coefficient of determination $\left(\mathrm{R}^{2}\right)$, and predicted relevance $\left(\mathrm{Q}^{2}\right)$. The statistical value in the inner model is presented in Table 3. It shows the t-statistics value ranging from 6.8 to 10.2 , which was greater than the t-table value of 1.96 . It can be concluded that all the relationships between the influence of facilities, inventory, transportation, information, 
sourcing, and pricing factors on SMEs' competitive supply chain strategy factors were significant. This test's results answered the hypotheses H1; H2; H3; H4; H5; H6.

Table 2. Outer Model Testing Results

\begin{tabular}{|c|c|c|c|c|c|}
\hline \multirow[b]{2}{*}{ Factor Variables } & \multirow[b]{2}{*}{ Indicators } & \multicolumn{3}{|c|}{ Validity Test } & \multirow{2}{*}{$\begin{array}{c}\text { Reliability } \\
\text { Test } \\
\text { CR }\end{array}$} \\
\hline & & Loading factor & AVE & $\begin{array}{l}\text { Weight Indicators } \\
\text { (P-value) }\end{array}$ & \\
\hline \multirow{4}{*}{ Facilities } & Capacity & 0.67 & \multirow{4}{*}{0.5} & $0.26(0.000)$ & \multirow{4}{*}{0.78} \\
\hline & Flow Time & 0.65 & & $0.31(0.000)$ & \\
\hline & Location & 0.74 & & $0.42(0.000)$ & \\
\hline & Utility & 0.7 & & $0.45(0.000)$ & \\
\hline \multirow{4}{*}{ Inventory } & Average & 0.67 & \multirow{4}{*}{0.44} & $0.39(0.000)$ & \multirow{4}{*}{0.76} \\
\hline & FillRate & 0.61 & & $0.23(0.000)$ & \\
\hline & Safety & 0.64 & & $0.40(0.000)$ & \\
\hline & Variation & 0.72 & & $0.51(0.000)$ & \\
\hline \multirow{5}{*}{ Transportation } & Cost & 0.69 & \multirow{5}{*}{0.5} & $0.28(0.000)$ & \multirow{5}{*}{0.83} \\
\hline & Incoming Size & 0.79 & & $0.39(0.000)$ & \\
\hline & Model & 0.71 & & $0.23(0.000)$ & \\
\hline & Outbond Size & 0.72 & & $0.26(0.000)$ & \\
\hline & Route & 0.62 & & $0.25(0.000)$ & \\
\hline \multirow{2}{*}{ Information } & EDI & 0.95 & \multirow{2}{*}{0.78} & $0.72(0.000)$ & \multirow{2}{*}{0.88} \\
\hline & Media & 0.81 & & $0.39(0.000)$ & \\
\hline \multirow{5}{*}{ Sourcing } & $\begin{array}{l}\text { Lead Time } \\
\text { Supply }\end{array}$ & 0.62 & \multirow{5}{*}{0.52} & $0.27(0.000)$ & \multirow{5}{*}{0.84} \\
\hline & Price Purchase & 0.74 & & $0.25(0.000)$ & \\
\hline & Quality Supply & 0.81 & & $0.35(0.000)$ & \\
\hline & $\begin{array}{l}\text { Quantity } \\
\text { Purchase }\end{array}$ & 0.68 & & $0.25(0.000)$ & \\
\hline & $\begin{array}{l}\text { Selection } \\
\text { Supplier }\end{array}$ & 0.73 & & $0.27(0.000)$ & \\
\hline \multirow{4}{*}{ Pricing } & $\begin{array}{l}\text { Day } \\
\text { Outstanding }\end{array}$ & 0.62 & \multirow{4}{*}{0.4} & $0.30(0.013)$ & \multirow{4}{*}{0.69} \\
\hline & Profit Margin & 0.52 & & $0.28(0.002)$ & \\
\hline & SalePrice & 0.79 & & $0.71(0.000)$ & \\
\hline & Supplier Price & 0.43 & & $0.24(0.019)$ & \\
\hline \multirow{2}{*}{$\begin{array}{l}\text { Competitive } \\
\text { supply chain } \\
\text { strategies }\end{array}$} & Efficiency & 0.87 & \multirow{2}{*}{0.75} & $0.59(0.000)$ & \multirow{2}{*}{0.86} \\
\hline & Responsive & 0.86 & & $0.57(0.000)$ & \\
\hline
\end{tabular}

Table 3. Inner model test results

\begin{tabular}{|c|c|c|c|c|c|}
\hline No & Exogenous to endogenous factors & $\begin{array}{l}\text { Influence } \\
\text { coefficient }\end{array}$ & $\begin{array}{c}\mathrm{t}- \\
\text { Statistics }\end{array}$ & $\mathrm{R}^{2}$ & $\mathrm{Q}^{2}$ \\
\hline 1 & Facilities to competitive strategies & 0.251 & 8.140 & \multirow{6}{*}{0.97} & \multirow{6}{*}{0.68} \\
\hline 2 & Inventory to competitive strategies & 0.221 & 6.781 & & \\
\hline 3 & Transportation to competitive strategies & 0.258 & 8.534 & & \\
\hline 4 & Information to competitive strategies & 0.202 & 6.976 & & \\
\hline 5 & Sourcing to competitive strategies & 0.294 & 10.161 & & \\
\hline 6 & Pricing to competitive strategies & 0.234 & 7.548 & & \\
\hline
\end{tabular}


Table 3 shows the $R^{2}$ value of 0.97 . It can be interpreted that the contribution of the variation of the exogenous factors logistical-crossfunctional drivers to the endogenous factors of the supply chain competition strategy of SMEs was $97 \%$. Based on this value, the model was categorized as good. Furthermore, the value of $\mathrm{Q}^{2}$ was 0.68 , which was much greater than zero. With the magnitude of the Q2 value, it can be concluded that the prediction model was relevant. Based on the $\mathrm{R}^{2}$ and $\mathrm{Q}^{2}$ values, it was concluded that the prediction model made was good and relevant. The results of this evaluation prove the major hypothesis.

\subsection{Model Analysis}

The results of the prediction model above became the basis for the identification of supply chain strategies. The visual image of the prediction model's results for SMEs' competitive supply chain strategy is presented in Fig. 2. It shows the loading factor, the coefficient of influence, t-statistics, and efficient, responsive, and competitive supply chain strategies. Based on the t-statistics value, it can be concluded that all aspects of the logistical-cross-functional drivers of SMEs were significant and affected the supply chain competitive strategy. The study results found that the facility aspect affects the supply chain competitive strategy. This study's results are consistent with research conducted by Masudin [19] and Madyaratry, et al. [7]. In their study, they proved that improvements to more modern facilities boost supply chain competitive strategies.

On the other hand, the inventory aspect also affects the supply chain competitive strategy. It is in line with the research findings conducted by Eicker and Cilliers [5] and Sasongko [9]. Their research indicated that an inventory that is in accordance with the needs, both the number and the variation, positively impact the supply chain competitive strategy.

In other aspects, transportation, information, sourcing, and pricing also significantly affect the supply chain competitive strategy. The transportation aspect findings are consistent with the research conducted by Ong, et al. [10] and Kantari, et al. [22]. They explained that transportation has an impact on the supply chain's competitive strategy. The information aspect findings are in line with Qosasi, et al. [20] and Mas'udin and Kamara [21]. The research results proved that the use of information technology could develop the competitive level of SMEs. The findings of the sourcing aspect are consistent with research conducted by Ortt, et al. [13], Galankashi and Helmi [14], Gandhi, et al. [15], which emphasized that quality supplier sourcing has an impact on supply chain competitive strategies. The pricing aspect's findings are in line with the research of Yu and Zhang [23] and Gan, et al. [24], which underlined that pricing impacts the competitive strategy of the supply chain of SMEs.

Based on Fig. 2, The value of the effect of logistical-crossfunctional drivers on the competitive supply chain of MSMEs has the same relative value. The influence value ranges from 0.20 to 0.29 , which shows there is no significant difference. However, based on six factors, the Sourcing factor has a dominant influence compared to other factors.

\subsection{Discussion}

SME facilities' influence on supply chain competitive strategy has the most significant influence compared to other factors. It means that the better the SME facilities, the more competitive the supply chain is. This finding is in line with the research of Madyaratry, et al. [7], who found that changing the facilities from semi-modest to more modern equipment certainly increases the level of competitiveness. Currently, there are still many UKM whose facilities aspects are less than optimal. To be able to compete, 
SMEs need a large amount of money to increase production capacity. However, the capital of SMEs is still low. In the facility indicator, production capacity has the most dominant influence. This finding is consistent with the results of Mas'udin and Kamara [21], which showed that allocation capacity affects competitive supply chains. Therefore, increasing production capacity is an essential solution while still referring to the trade-off of efficiency and responsiveness.

The SME sourcing factor to the supply chain competitive strategy contributed the second largest. It shows that the better the SME sourcing, the more it will positively impact the supply chain competitive strategy. This result is relevant to the research of Ortt, et al. [13], Galankashi and Helmi [14], Gandhi, et al. [15]. Sourcing from quality suppliers has an impact on a competitive supply chain. Currently, the constraints of SME sourcing aspects such as lack of HR skills [1] [9], lack of network relationships, limited suppliers [12] [13], and lack of partnerships are the real obstacles. This study implies that it is necessary to improve the sourcing of SMEs through the average purchase quantity. This finding is by the results of research by Ortt, et al. [13], Galankashi and Helmi [14], Gandhi, et al. [15] related to the number of suppliers that must be stable according to the order.

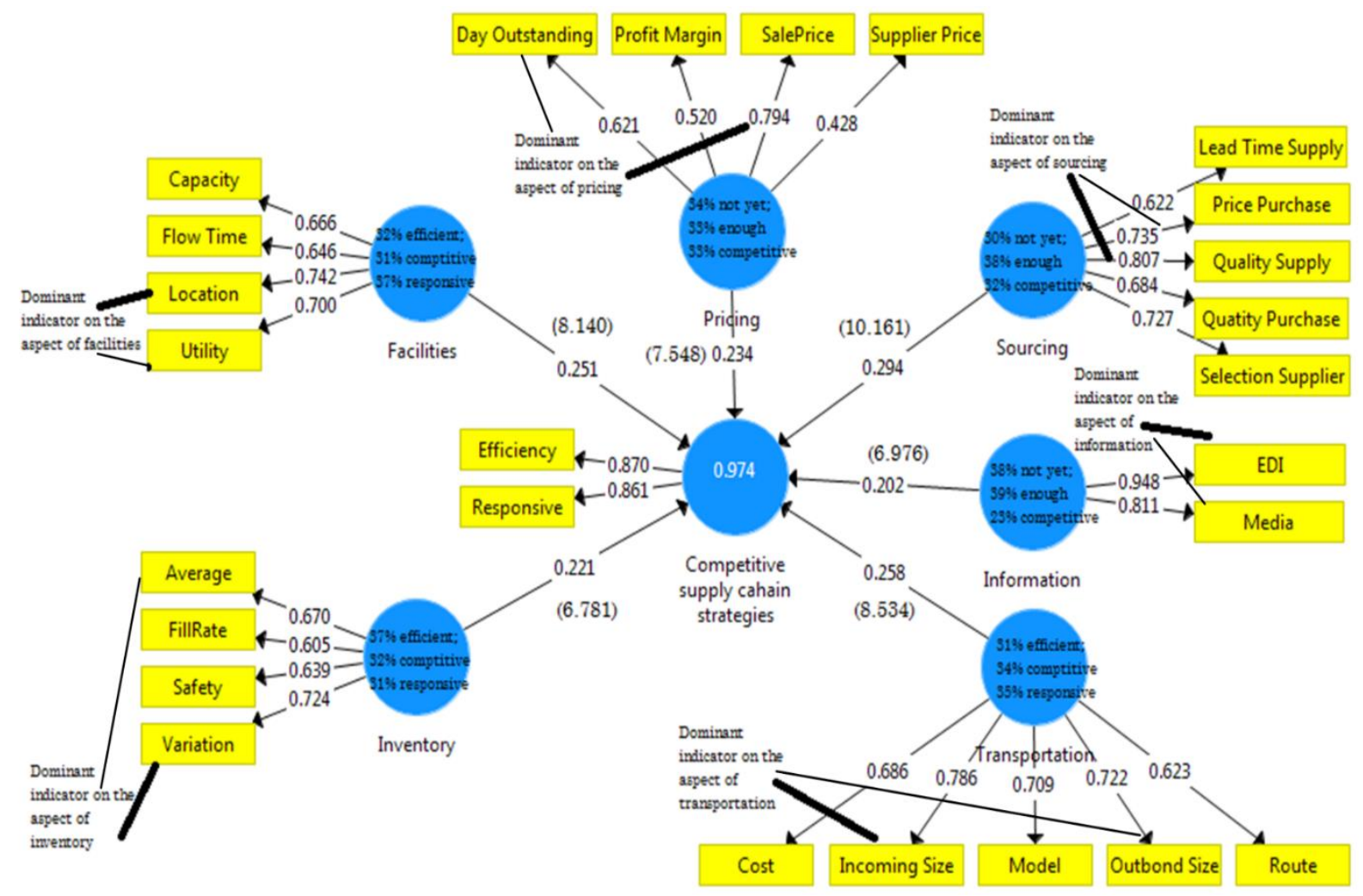

Fig. 2. The results of the logistical-crossfunctional drivers model on the competitive strategy of the supply chain for SMEs

The information aspect of SMEs on the competitive supply chain has the third most significant influence. It indicates that the better the information aspects of SMEs, the more positive they will have on the supply chain competitive strategy. This result is from the research of Qosasi, et al. [20]. The use of information technology can develop the 
competitive level of SMEs. In line with Sari's research results, SMEs need to prepare an information strategy in the industrial era 4.0, especially using information technology. Currently, not all SMEs can take advantage of information technology due to the lack of human resource capabilities [1]. This research result implies that it is necessary to improve the information aspect of UKM through information technology. This study's results are consistent with the research of Qosasi, et al. [20], Mas'udin and Kamara [21], which stated that the application of information technology could develop a competitive level, facilitate SME innovation and improve service to consumers.

The influence of the transportation aspects of SMEs on the competitive supply chain has the fourth-largest influence. This fact shows that the better the transportation aspects of SMEs, the more positive impacts on the supply chain competitive strategy. These results are consistent with the studies of Ong, et al. [10] and Kantari, et al. [22]. Determination of suitable transportation routes and delivery of appropriate orders impacts customer service and loyalty. This research implies that it is necessary to improve SMEs' transportation aspects by implementing transportation according to the route and accurate delivery according to the orders.

Meanwhile, the effect of SMEs' inventory aspect on the competitive supply chain has the fifth largest contribution. This datum underlines that the more appropriate the SME inventory is, the more positive impact on the supply chain's competitive strategy. These results are consistent with research conducted by Eicker and Cilliers [5] and Sasongko [9], which show that the number and variation of inventories impact supply chain competitive strategies. Currently, many SMEs do not have good inventory management. This research result implies that it is necessary to improve the inventory aspect of SMEs.

Finally, the pricing aspect of SMEs has the sixth-largest influence on competitive supply chains. The more appropriate pricing for SMEs, the more positive impact on supply chain competitive strategies. This result is in line with the research of Yu and Zhang [23], [24], which explained that the determination of selling price has an impact on supply chain performance and profit performance. Currently, many SMEs do not have good pricing management. This study implies that it is necessary to improve SMEs' pricing aspect in getting the lowest supplier prices. Some of the efforts that need to be made include improving human resource skills through network relationships, partnerships, and participating in government assistance programs.

\section{Conclusion}

This study examines the effect of logistical-crossfunctional drivers on the competitive strategy of SMEs' supply chain. The results of model testing showed that the logistical-crossfunctional aspects of SME drivers have a significant influence on supply chain competitive strategies. The influence of logistical-crossfunctional drivers on supply chain competitive strategy is as follows: sourcing, facilities, information, transportation, inventory, and pricing. In this study, the business sector was not taken into consideration in the study. For further research, it is necessary to compare competitive supply chain strategy models based on various SME business sectors such as trade, agriculture, and manufacturing. The comparison of models in each sector provides more detailed and specific results to determine the differences in each sector. Therefore, it is expected that it can be used to develop the logistical-crossfunctional aspects of competitive and more focused drivers and adaptive. 


\section{Acknowledgment}

Sincere gratitude is delivered to the Directorate of Research and Community Service, Deputy of Research and Development Strengthening, Ministry of Research and Technology-National Agency for Research and Technology for financing the Beginner Lecturer Research scheme for the 2020 fiscal year, so that this scientific article can be structured and published according to the research objectives.

\section{References}

[1] T. Tambunan, "Recent evidence of the development of micro, small and medium enterprises in Indonesia," Journal of Global Entrepreneurship Research, vol. 9, p. 18, 2019. https://doi.org/10.1186/s40497-018-0140-4.

[2] S. Chopra and P. Meindl, "Supply Chain Management," in Supply Chain Management, 5th Edition ed New Jersey-USA: Prentice Hall, 2019.

[3] I. N. Pujawan and E. Mahendrawathi, Supply Chain Management, Ketiga ed. Yogyakarta: Andi Publiser, 2017.

[4] S. A. Helmi, F. M. Rafiei, M. Rahiminezhad Galankashi, and A. R. Abdul Rahim, "Agility assessment in manufacturing companies," Benchmarking: An International Journal, vol. 26, pp. 2081-2104, 2019. https://doi.org/10.1108/BIJ-102018-0328.

[5] T. Eicker and J. O. Cilliers, "Managing logistical supply chain drivers: A predictor of small township retailers' odds of survival," Acta Commercii, vol. 19, pp. 1-12, 2019. http://dx.doi.org/10.4102/ac.v19i2.590

[6] S. M. S. Rana, "Supply chain drivers and retail supply chain responsiveness: strategy as moderator," International Journal of Management Practice, vol. 13, pp. 1-22, 2019. https://doi.org/10.1504/IJMP.2020.104066.

[7] L. H. Madyaratry, H. Hardjomidjojo, and E. Anggraeni, "The Mapping of Sustainability Index in Small and Medium Enterprises: A Case Study in Lampung Indonesia," Jurnal Teknik Industri; Vol 21, No 1 (2020): February, 2020. https://doi.org/10.22219/JTIUMM.Vol21.No1.58-69.

[8] D. Rita, "Analisis Aksesibilitas Permodalan Usaha Mikro Kecil Di Provinsi Sumatera Barat," Jurnal Ekonomi dan Pembangunan, vol. 27, 2019. https://doi.org/10.14203/JEP.27.1.2019.67-80.

[9] W. Sasongko, "Strategi Dinas Koperasi Dan Umkm Kabupaten Jombang Dalam Meningkatkan Daya Saing Umkm Untuk Menghadapi Asean Economic Community 2016," Universitas Airlangga, vol. 4, 2016.

[10] C. H. Ong, S. M. Salleh, and R. Z. Yusoff, "The role of emotional and rational trust in explaining attitudinal and behavioral loyalty: An insight into SME brands," Gadjah Mada International Journal of Business, vol. 18, pp. 1-19, 2016. https://doi.org/10.3316/informit.010526072986480.

[11] R. P. Sari and D. T. Santoso, "Readiness Factor Identification on Kabupaten Karawang SMEs towards Industry 4.0 Era," Jurnal Teknik Industri, vol. 22, pp. 65-74, 2020. https://doi.org/10.9744/jti.22.1.65-74.

[12] M. D. Revindo, C. Gan, and N. W. G. Massie, "Factors affecting propensity to export: The case of Indonesian SMEs," Gadjah Mada International Journal of Business, vol. 21, pp. 263-288, 2019. https://doi.org/10.22146/gamaijb.41022.

[13] R. Ortt, J. Rezaei, and P. Trott, "Supply chain drivers, partnerships and performance of high-tech SMEs," International Journal of Productivity and Performance Management, vol. 67, pp. 629-653, 2018. https://doi.org/10.1108/IJPPM-01-2017-0017. 
[14] M. R. Galankashi and S. A. Helmi, "Assessment of lean manufacturing practices: an operational perspective," International Journal of Services and Operations $\begin{array}{lllll}\text { Management, } & \text { vol. } & \text { 28, } & \text { pp. } & 163-184,\end{array}$ https://doi.org/10.1504/IJSOM.2017.086308.

[15] S. K. Gandhi, A. Sachdeva, and A. Gupta, "Measuring Supplier Service Quality in Indian SMEs Using Factor Analysis \& GTA," Jurnal Teknik Industri, vol. 20, pp. 11-24, 2018. https://doi.org/10.9744/jti.20.1.11-24.

[16] J. M. Panjaitan, M. Darwina, I. Bastian, and S. Sukamdi, "What do banks, rural credit institutions, and regulators infer from the current strengths and standing of Indonesian SMEs?," Gadjah Mada International Journal of Business, vol. 22, pp. 1-23, 2020. https://doi.org/10.22146/gamaijb.53968.

[17] K. Ganguly and G. Kumar, "Supply chain risk assessment: a fuzzy AHP approach," Operations and Supply Chain Management: An International Journal, vol. 12, pp. 1-13, 2019. http://doi.org/10.31387/oscm0360217.

[18] W. Wulandari, R. N. Sari, and L. Al Azhar, "Pengaruh Supply Chain Management Terhadap Kinerja Perusahaan Melalui Keunggulan Bersaing," Jurnal Ekonomi, vol. 21, pp. 462-479, 2017. http://dx.doi.org/10.24912/je.v21i3.31.

[19] I. Masudin, "Location-allocation problems in the perspective of supply chain: Approaches and applications," Jurnal Teknik Industri, vol. 20, pp. 1-11, 2019. https://doi.org/10.22219/JTIUMM.Vol20.No1.1-11.

[20] A. Qosasi, E. Permana, A. Muftiadi, M. Purnomo, and E. Maulina, "Building SMEs' Competitive Advantage and the Organizational Agility of Apparel Retailers in Indonesia: The role of ICT as an Initial Trigger," Gadjah Mada International Journal of Bussiness, vol. 21, p. 23, 2019. https://doi.org/10.22146/gamaijb.39001.

[21] I. Mas'udin and M. S. Kamara, "Electronic Data Interchange and Demand Forecasting Implications on Supply Chain Management Collaboration: A Customer Service Perspective," Jurnal Teknik Industri, vol. 18, pp. 138-148, 2017. https://doi.org/10.22219/JTIUMM.Vol18.No2.138-148.

[22] L. A. Kantari, I. N. Pujawan, N. I. Arvitrida, and P. Hilletofth, "Investigating the mix of contract-based and on-demand sourcing for transportation services under fluctuate and seasonal demand," International Journal of Logistics Research and Applications, pp. 1-23, 2020. https://doi.org/10.1080/13675567.2020.1751807.

[23] L. Yu and J. Zhang, "A two-period pricing model with hunger marketing strategy," Journal of Modelling in Management, vol. 13, pp. 81-100, 2018. https://doi.org/10.1108/JM2-02-2016-0012.

[24] S.-S. Gan, I. N. Pujawan, Suparno, and B. Widodo, "Pricing decision for new and remanufactured product in a closed-loop supply chain with separate saleschannel," International Journal of Production Economics, vol. 190, pp. 120-132, 2017. https://doi.org/10.1016/j.ijpe.2016.08.016.

[25] BPS-Jombang, "Potensi Sentra Industri Kecil Dan Menengah Tahun 2017," B. P. Statistik, Ed., ed. Jombang, 2018.

[26] J. F. Hair, G. T. M. Hult, C. M. Ringle, M. Sarstedt, and K. O. Thiele, "Mirror, mirror on the wall: a comparative evaluation of composite-based structural equation modeling methods," Journal of the Academy of Marketing Science, vol. 45, pp. 616-632, 2017. https://doi.org/10.1007/s11747-017-0517-x.

[27] M. Sarstedt, J. F. Hair, J.-H. Cheah, J.-M. Becker, and C. M. Ringle, "How to specify, estimate, and validate higher-order constructs in PLS-SEM," Australasian Marketing Journal (AMJ), vol. 27, pp. 197-211, 2019. https://doi.org/10.1016/j.ausmj.2019.05.003. 
[28] C. M. Ringle, J. F. Hair, G. F. Khan, M. Sarstedt, W.-L. Shiau, and M. P. Fritze, "Methodological research on partial least squares structural equation modeling (PLS-SEM)," Internet Research, vol. 29, pp. 407-429, 2019. https://doi.org/10.1108/IntR-12-2017-0509.

[29] E. Tsanaktsidou, C. Karavasili, C. K. Zacharis, D. G. Fatouros, and C. K. Markopoulou, "Partial Least Square Model (PLS) as a Tool to Predict the Diffusion of Steroids Across Artificial Membranes," Molecules, vol. 25, 2020. https://doi.org/10.3390/molecules25061387.

[30] M. Sarstedt, C. Ringle, and J. Hair, "Partial Least Squares Structural Equation Modeling," in Handbook of Market Research, ed: Springer, 2017. https://doi.org/10.1007/978-3-319-05542-8_15-1.

[31] C. M. Ringle, J. F. Hair, J. J. Risher, and M. Sarstedt, "When to use and how to report the results of PLS-SEM," European Business Review, vol. 31, pp. 2-24, 2019. https://doi.org/10.1108/EBR-11-2018-0203.

[32] J. F. Hair, C. M. Ringle, J. J. Risher, and M. Sarstedt, "When to use and how to report the results of PLS-SEM," European Business Review, vol. 31, pp. 2-24, 2019. https://doi.org/10.1108/EBR-11-2018-0203.

[33] J. F. Hair Jr, G. T. M. Hult, C. Ringle, and M. Sarstedt, A primer on partial least squares structural equation modeling (PLS-SEM): Sage publications, 2016.

[34] N. Malik, "The Influence of Turnover Factors Toward Employees' Intention to Stay: A Case Study in Indonesian Islamic Universities," Jurnal Teknik Industri, vol. 21, pp. 80-91, 2020. https://doi.org/10.22219/JTIUMM.Vol21.No1.80-91.

[35] I. Giyanti and E. Indriastiningsih, "Effect of SME Food Entrepreneurs Knowledge on Halal Certification for Certified Awareness Using Partial Least Square," Jurnal Teknik Industri, vol. 20, pp. $140-151, \quad 2019$. https://doi.org/10.22219/JTIUMM.Vol20.No2.140-151.

[36] F. Tentama and S. Subardjo, "Pengujian validitas dan reliabilitas konstruk pada organizational citizenship behavior," Humanitas, vol. 15, pp. 62-71, 2018. https://doi.org/10.26555/humanitas.v15i1.5282. 